\title{
EKSISTENSI HUKUM EKONOMI SYARIAH DALAM HUKUM PERDATA
}

\author{
Maulana Ira \\ Sekolah Tinggi Agama Islam Aceh Tamiang (STAI-AT) \\ moelmaulana1@gmail.com
}

\begin{abstract}
The history of the positiveization of Islamic civil law was carried out by the Ottoman Government in enforcing the Islamic Civil Code which consisted of 1851 articles. On the other hand, the "positivization" of Islamic civil law is the realization of the dream of Muslims since ancient times, during the Dutch East Indies government the Civil Code (KUHPerdata) was still applied, which was a translation of the Dutch Colonial Borgelijk Wetbook (BW). For now, the positiveization of Sharia Economic Law has become a necessity for Muslims, considering that sharia economic practices are increasingly developing through Sharia Financial Institutions. The compilation is then used as a reference in the settlement of sharia economic cases which are increasing day by day, along with the development of the Islamic Financial Institution as well. This paper seeks to examine Sharia Economic Law, Civil Law, Sharia Economic Law Materials in Civil Law and Efforts to Positivity Sharia Economic Law in Indonesia.
\end{abstract}

Keywords: Civil Law, Sharia Economic Law, existence

\begin{abstract}
Abstrak
Sejarah positifisasi hukum perdata Islam pernah dilakukan oleh Pemerintahan Turki Usmani dalam memberlakukan Kitab Hukum Perdata Islam yang terdiri dari 1851 pasal. Disisi lain, "positifisasi" hukum perdata Islam merupakan realisasi impian umat Islam sejak zaman dahulu, pada masa pemerintahan Hindia Belanda masih diterapkan Kitab Undangundang Hukum Perdata (KUHPerdata) yang merupakan terjemahan dari Borgelijk Wetbook (BW) karya Kolonial Belanda. Untuk saat ini, positifisasi Hukum Ekonomi Syariah sudah menjadi keniscayaan bagi umat Islam, mengingat praktek ekonomi syari'ah sudah semakin berkembang melalui Lembaga Keuangan Syariah. Kompilasi tersebut kemudian dijadikan acuan dalam penyelesaian perkara-perkara ekonomi syari'ah yang semakin hari semakin bertambah, seiring dengan perkembangan Lembaga Keuangan Syariah itu juga. Tulisan ini berupaya untuk mengkaji Tentang Hukum Ekonomi Syariah, Hukum Perdata, Materi Hukum Ekonomi Syariah Dalam
\end{abstract}


Hukum Perdata serta Upaya Positifisasi Hukum Ekonomi Syariah di Indonesia.

Kata Kunci: Hukum Perdata, Hukum Ekonomi Syariah, Eksistensi.

\section{Pendahuluan}

Implementasi nilai-nilai Islam dalam ekonomi syari'ah setidaknya dapat dipahami dalam dimensi inklusif dan eksklusif (Hamid, 2007: 22). Secara ekslusif, artinya menempatkan syari'ah dalam posisi internal dan integratif dari ajaran Islam sebagai sebuah kesatuan yang sistematis menyeluruh (kaffah), dan mandiri. Secara internal, semua pemeluk Islam (muslim) mutlak menempatkan syari'ah di atas segala-galanya yang harus pula terimplementasi dalam segala dimensi kehidupan, tak terkecuali di bidang ekonomi. Dalam Realitas semacam ini, sistem ekonomi syari'ah merupakan pilihan yang tidak mungkin ditawar lagi. Dengan tidak menempatkan syari'ah dalam setiap dimensi kehidupannya, akan berakibat fatal karena telah melakukan pengingkaran terhadap pesan al-Qur'an untuk menerapkan nilainilai Islam secara kaffah (udkhulu fi-as-silmi kaffah).

Secara inklusif, artinya menempatkan syari'ah bukan dalam posisi yang mandiri terlepas dari sistem-sistem yang berkembang disekitarnya, melainkan harus dipandang sebagai bagian sistem kehidupan secara keseluruhan. Dari perspektif ini, ekonomi syari'ah merupakan salah satu sistem dari beberapa sistem ekonomi yang ada di dunia. Secara inklusivistik, sistem ekonomi syari'ah haruslah diposisikan sebagai alternatif di antara sistem-sistem ekonomi konvensional yang ada dan berkembang saat ini. Artinya, sistem ekonomi syari'ah tidak berbeda dengan yang lainnya yang bisa dipilih ataupun tidak dipilih. Hal ini sangat bergantung pada selera, keyakinan, sistem, dan keunggulan kompetitif yang melekat didalamnya atau karena pertimbangan khusus lainnya (Hamid, 2007: 22-23).

Krisis ekonomi yang terjadi di Indonesia, termasuk krisis perbankan yang menyebabkan kepercayaan nasabah turun secara drastis, menjadikan pemerintah mulai melirik pada sistem yang berangkat dari sistem ekonomi syari'ah lewat keberadaan perbankan syari'ah di Indonesia, hal itu karena lembaga keuangan syari'ah berperan penting dalam pemulihan perekonomian Indonesia (Sabirin, 2003: 393). Terbitnya regulasi tentang perbankan syari'ah merupakan sebuah momentum pengembangan perbankan syari'ah di Indonesia. Undang-undang menjadi landasan kuat berdirinya sistem ekonomi syariah di Indonesia dalam menjawab tantangan krisis yang ada. Dengan lahirnya sejumlah peraturan perundang-undangan yang berkaitan dengan perbankan syariah, menunjukkan pemberlakuan hukum Islam dalam konteks kenegaraan tidak sebatas pada hal-hal yang bersentuhan dengan bidang ibadah tetapi juga menyentuh bidang muamalah, khususnya dalam bidang ekonomi. 
Perkembangan Ekonomi Syariah di tanah air dalam beberapa tahun terakhir menunjukkan perkembangan yang amat pesat. Kemunculan lembaga-lembaga ekonomi syariah, baik bank maupun non-bank, menjadi fenomena yang menarik perhatian banyak pihak. Dengan demikian, mutlak diperlukan piranti hukum yang mampu menopang kebutuhan lembaga tersebut secara tepat dan kuat di Indonesia dengan tetap berpegang pada nilai-nilai Islam. Islam sebagai agama yang dipeluk oleh mayoritas penduduk Indonesia, tentu sangat berpengaruh terhadap pola hidup bangsa Indonesia (Kholid, 2018). Perilaku pemeluk agama Islam tidak lepas dari syari'at agamanya. Ooleh karena itu, pelaksanaan syari'at yang berupa hukum-hukum merupakan salah satu parameter ketaatan seseorang dalam menjalankan agamanya.

Istilah ekonomi syari'ah dikenal di Indonesia, sementara di negaranegara lain, istilah tersebut dikenal dengan nama ekonomi Islam (Islamic economy). Ekonomi Islam berbeda dengan ekonomi konvensional yang berkembang (ARFAH et al., 2020). Perbedaan terutama dikarenakan, ekonomi Islam terikat pada nilai-nilai agama Islam, sedangkan ekonomi konvensional memisahkan diri dari agama sejak negara-negara Barat berpegang pada sekularisme dengan konsekuensi menjalankan politik sekularisasi (Ahmad, 1983: 12-17). Meski demikian, pada dasarnya tidak ada ekonomi yang terpisah dari nilai atau tingkah laku manusia. Namun, pada ekonomi konvensional, nilai yang digunakan adalah nilai-nilai duniawi semata (profane, mundane).

Kajian ilmu ekonomi secara umum pada hakikatnya menyangkut sikap tingkah laku manusia terhadap masalah produksi, distribusi, konsumsi barang-barang komoditi serta pelayanan. Kajian ilmu ekonomi Islam dari segi ini tidak berbeda dari ekonomi sekuler, akan tetapi dari segi lain ia terikat dengan nilai-nilai Islam atau halal dan haram, sementara persoalan halal-haram merupakan salah satu lingkup kajian hukum, maka hal tersebut menunjukkan keterkaitan yang erat antara hukum, ekonomi dan syariah (Kahf, 1987: 11).

Disahkannya UU No 3 Tahun 2006 tentang Perubahan atas UU No 7 Tahun 1989 tentang Peradilan Agama, oleh Presiden Republik Indonesia membawa implikasi besar terhadap perundang-undangan yang mengatur harta benda, bisnis dan perdagangan secara luas. Pasal 49 point i disebutkan bahwa Pengadilan Agama bertugas dan berwenang memeriksa, memutus dan menyelesaikan perkara di tingkat pertama antara orangorang yang beragama Islam di bidang ekonomi syariah. Dalam penjelasannya, disebutkan yang dimaksud dengan ekonomi syariah adalah perbuatan atau kegiatan usaha yang dilaksanakan menurut prinsip syari'ah, antara lain meliputi: a. Bank syariah, b. Lembaga keuangan mikro syari'ah, c. asuransi syari'ah, d. reasurasi syari'ah, e. reksadana syari'ah, f. obligasi syariah dan surat berharga berjangka menengah syariah, g. sekuritas syariah, h. Pembiayaan syari'ah, i. Pegadaian syari'ah, j. dana pensiun lembaga keuangan syari'ah dan k. bisnis syari'ah 
Perubahan tersebut membawa dampak baru dalam sejarah hukum ekonomi di Indonesia. Selama ini, wewenang untuk menangani sengketa dalam bidang ekonomi syariah diselesaikan di Pengadilan Negeri. Dalam prakteknya, sebelum perubahan UU No. 7 Tahun 1989, penegakkan hukum kontrak bisnis di lembaga-lembaga keuangan syariah tersebut mengacu pada ketentuan KUHPerdata yang merupakan terjemahan dari Burgerlijk Wetboek (BW), kitab Undang-undang hukum sipil Belanda yang dikoordinasi keberlakuannya di tanah Jajahan Hindia Belanda tahun 1854, sehingga konsep perikatan dalam Hukum Islam tidak lagi berfungsi dalam praktek formalitas hukum di masyarakat, namun yang berlaku adalah BW.

Secara historis, norma-norma yang bersumber dari hukum Islam di bidang perikatan telah lama memudar dari perangkat hukum yang ada akibat politik Penjajah yang secara sistematis mengikis keberlakuan hukum Islam. Akibatnya, lembaga perbankan maupun di lembaga-lembaga keuangan lainnya, sangat terbiasa menerapkan ketentuan Buku Ke tiga BW (Burgerlijk Wetboek) yang sudah diterjemahkan. Sehingga untuk memulai suatu transaksi secara syariah tanpa pedoman teknis yang jelas akan sulit sekali dilakukan. Ketika wewenang mengadili sengketa hukum ekonomi syariah menjadi wewenang absolut hakim pengadilan agama, maka dibutuhkan adanya kodifikasi hukum ekonomi syariah yang lengkap agar hukum ekonomi syariah memiliki kepastian hukum dan para hakim memiliki rujukan standarisaai dalam menyelesaikan kasus-kasus sengketa di dalam bisnis syari'ah (Fathonih et al., 2019).

Kedudukan KHI secara konstitusional masih sangat lemah karena keberadaannya sebatas Inpres. Karena itu dibutuhkan suatu aturan hukum yang lebih kuat yang dapat menjadi rujukan para hakim dalam memutuskan berbagai persoalan hukum. Untuk itulah perlu merumuskan Kodifikasi Hukum Ekonomi Islam, sebagaimana yang dibuat pemerintahan Turki Usmani bernama Al-Majallah Al-Ahkam al-'Adliyah yang terdiri dari 1851 pasal. Kodifikasi merupakan himpunan berbagai peraturan menjadi undang-undang. Dalam sejarahnya, formulasi suatu hukum dibuat secara tertulis yang disebut jus scriptum. Setelah jumlah peraturan itu menjadi demikian banyak, maka dibutuhkan sebuah kodifikasi hukum yang menghimpun berbagai macam peraturan perundang-undangan (Mingka, n.d.).

\section{Hukum Perdata}

Pada Tahun 1814 Belanda memulai penyusunan Kitab UndangUndang Hukum Perdata, berdasarkan kodifikasi hukum Belanda yang dibuat oleh J.M. Kemper disebut Ontwerp Kemper. Namun, Kemper meninggal dunia pada 1824 sebelum menyelesaikan tugasnya dan dilanjutkan oleh Nicolai yang menjabat sebagai Ketua Pengadilan Tinggi Belgia. Keinginan Belanda terealisasi pada tanggal 6 Juli 1880 dengan pembentukan dua kodifikasi yang baru diberlakukan pada tanggal 1 Oktober 1838, yaitu: 
1. BW (atau Kitab Undang-Undang Hukum Perdata-Belanda).

2. WvK (atau yang dikenal dengan Kitab Undang-Undang Hukum Dagang]

Hukum perdata yang berlaku di Indonesia adalah hukum perdataa Belanda yang pada awalnya berinduk pada Kitab Undang-Undang Hukum Perdata yang aslinya berbahasa Belanda atau dikenal dengan Burgerlijk Wetboek dan biasa disingkat dengan BW. Sebagian materi BW sudah dicabut berlakunya dan sudah diganti dengan Undang-Undang RI, misalnya mengenai UU Perkawinan, UU Hak Tanggungan, dan UU Kepailitan.

Kodifikasi KUHPerdata Indonesia diumumkan pada tanggal 30 April 1847 melalui Staatsblad Nomor 23 dan berlaku Januari 1848. Setelah Indonesia Merdeka, berdasarkan Pasal 2 aturan peralihan Undang-Undang Dasar 1945, KUHPerdata Hindia Belanda tetap dinyatakan berlaku sebelum digantikan dengan Undang-Undang baru berdasarkan UndangUndang Dasar ini. BW Hindia Belanda merupakan induk hukum perdata Indonesia.

Kitab undang-undang hukum perdata terdiri dari empat bagian yaitu:

1. Buku I tentang Orang; mengatur tentang hukum perseorangan dan hukum keluarga, yakni hukum yang mengatur status serta hak dan kewajiban yang dimiliki oleh subyek hukum. Antara lain ketentuan mengenai timbulnya hak keperdataan seseorang, kelahiran, kedewasaan, perkawinan, perceraian, keluarga, dan hilangnya hak keperdataan. Untuk perkawinan ketentuannya telah dinyatakan tidak berlaku dengan disahkannya Undang-Undang Nomor 1 tahun 1974 tentang perkawinan.

2. Buku II tentang Kebendaan; mengatur tentang hukum benda, yaitu hukum yang mengatur hak dan kewajiban yang dimiliki oleh subyek hukum yang berkaitan dengan benda, antara lain hak-hak kebendaan, waris dan penjaminan. Dimaksud dengan benda meliputi (i) benda berwujud tidak bergerak (misalnya tanah, bangunan dan kapal dengan berat tertentu); (ii) benda berwujud bergerak, yaitu benda berwujud lainnya selain yang dianggap sebagai benda berwujud tidak bergerak; dan (iii) benda tidak berwujud (misalnya hak tagih atau piutang). Khusus untuk bagian tanah, sebagian ketentuan dinyatakan tidak berlaku dengan di undangkannya Undang-Undang Nomor 5 Tahun 1960 tentang agraria. Begitu pula bagian mengenai penjaminan dengan hipotik, telah dinyatakan tidak berlaku dengan di undangkannya UU tentang hak tanggungan.

3. Buku III tentang Perikatan; mengatur tentang hukum perikatan yaitu hukum yang mengatur tentang hak dan kewajiban antara subyek hukum di bidang perikatan, antara lain tentang jenis-jenis perikatan (yang terdiri dari perikatan yang timbul dari 
(ditetapkan) undang-undang dan perikatan yang timbul dari adanya perjanjian), syarat dan tata cara pembuatan suatu perjanjian. Khusus untuk bidang perdagangan, Kitab undang-undang hukum dagang (KUHD) juga dipakai sebagai acuan. Isi KUHD berkaitan erat dengan KUHPerdata, khususnya Buku III. Bisa dikatakan KUHD adalah bagian khusus dari KUHPerdata.

4. Buku IV tentang Daluarsa dan Pembuktian; mengatur hak dan kewajiban subyek hukum, khususnya batas atau tenggat waktu dalam mempergunakan hak-haknya dalam hukum perdata dan halhal yang berkaitan dengan pembuktian.

\section{Materi Hukum Ekonomi Syariah Dalam Hukum Perdata}

\section{Harta Bersama}

Pasal $119 \mathrm{KUH}$ Perdata disebutkan bahwa mulai saat perkawinan dilangsungkan, secara hukum berlakulah kesatuan bulat antara harta kekayaan suami istri. Persatuan harta kekayaan itu sepanjang perkawinan dilaksanakan dan tidak boleh ditiadakan atau diubah dengan suatu persetujuan antara suami dan istri apa pun. Jikapun bermaksud mengadakan penyimpangan dari ketentuan tersebut, suami istri harus menempuh jalan dengan perjanjian kawin yang diatur dalam Pasal 139-154 KUH Perdata.

Perjanjian sebagaimana di atas, harus dilaksanakan sebelum perkawinan dilangsungkan dan harus dibuatkan dalam bentuk akta autentik di hadapan notaris, akta autentik sangat penting, karena dapat dijadikan bukti dalam persidangan pengadilan apabila terjadi sengketa di kemudian hari. Jika tidak ada perjanjian kawin yang dibuat sebelum perkawinan dilaksanakan, maka semua harta suami istri terjadi perbauran dan dianggap harta bersama. Selanjutnya Pasal 128-129 KUHPerdata, dinyatakan bahwa apabila putusnya tali perkawinan antara suami istri, maka harta bersama dibagi dua antara suami istri tanpa memperhatikan dari pihak mana barang-barang kekayaan itu sebelumna diperoleh. Tentang perjanjian kawin itu dibenarkan oleh perauran perundangundangan sepanjang tidak menyalahi tata susila dan ketentraman umum yang berlaku dalam kehidupan masyarakat.

Menurut Undang-Undang Nomor 1 Tahun 1974 tentang Perkawinan Pasal 35-37 dikemukakan bahwa harta benda yang diperoleh selama perkawinan menjadi harta bersama. Masing-masing suami istri terhadap harta yang diperoleh sebagai hadiah atau warisan adalah di bawah pengawasan masing-masing sepanjang para pihak tidak menentukan lain. Tentang harta bersama, suami atau istri dapat bertindak untuk berbuat sesuatu atau tidak berbuat sesuatu atas harta bersama itu atas persetujuan kedua belah pihak. Dinyatakan pula bahwa suami atau istri mempunyai hak sepenuhnya untuk melakukan perbuatan hukum mengenai harta bersama tersebut apabila perkawinan putus karena 
perceraian, maka harta bersama tersebut diatur menurut hukum masingmasing.

Menurut Pasal 36 Ayat (2) Undang-Undang Nomor 1 Tahun 1974 tentang Perkawinan jo. Pasal 87 Ayat (2) Kompilasi Hukum Islam bahwa istri mempunyai hak sepenuhnya unuk melakukan perbuatan hukum terhadap harta pribadi masing-masing. Mereka bebas menentukan terhadap harta tersebut tanpa ikut campur suami istri untuk menjualnya, dihibahkan, atau mengagunkan. Juga tidak diperlukan bantuan hukum dari suami untuk melakukan tindakan hukum atas pribadinya. Tidak ada perbdaan kemampuan hukum anara suami istri dalam menguasai dan melakukan tindakan terhadap harta benda pribadi mereka undang-undang tidak membedakan kemampuan melakukan tindakan hukum terhadap harta pribadi suami istri masing-masing. Ketentuan tersebut bisa dilihat dalam Pasal 86 Kompilasi Hukum Islam, yang mana ditegaskan bahwa tidak ada percampuran antara harta pribadi suami istri karena perkawinan dan harta istri tetap mutlak jadi hak istri dan dikuasai penuh olehnya, begitu juga harta pribadi suami menjadi hak mutlak dan dikuasai penuh olehnya.

Sebenarnya apa yang disebut dalam Pasal 35-37 Undang-undang Nomor 1 Tahun 1974 tentang Perkawinan sebagaimana tersebut di atas itu adalah sejalan dengan keentuan enang hukum adat yang berlaku di Indonesia. Dalam konsepsi hukum adat tentang harta bersama di Nusantara banyak ditemukan prinsip bahwa masing-masing suami istri berhak menguasai harta bendanya sendiri dan ini berlaku sebagaimana sebelum mereka menjadi suami istri. Hanya, apabila dilihat dari pendekatan filosofis, perkawinan tidak lain dari ikatan lahir batin di antara suami istri guna mewujudkan rumah tangga yang kekal dan penuh dalam suasana kerukunan, maka hukum adat yang mengharapkan adanya komunikasi yang terbuka dalam pengelolaan dan penguasaan harta pribadi tersebut, sangat perlu dikembangkan sikap saling menghormati, saling membantu, saling bekerja sama, dan saling bergantung. Dengan begitu, keabsahan menguasai harta pribadi masing-masing pihak, jangan sampai merusak tatanan kedudukan suami sebagai kepala keluarga dan istri sebagai ibu rumah tangga (Manan, 2008: 104-106).

2. Hibah

Dalam Islam, hibah berarti akad yang pokoknya adalah pemberian harta milik seseorang kepada orang lain di waktu ia masih hidup tanpa adanya imbalan apapun. Secara umum hibah mempunyai pengertian meliputi hal-hal : (1) yakni menghibahkan utang kepada yang berutang; (2) sedekah yakni menghibahkan sesuatu dengan harapan mendapat pahala di akhirat; (3) hadiah yakni pemberian yang menurut orang yang diberi itu memberi imbalan.

Dalam KUHPerdata, hibah disebut schenking yaitu sesuatu persetujuan dengan si pemberi hibah di waktu hidupnya dengan cumacuma dan dengan tidak ditarik kembali, menyerahkan sesuatu benda guna 
keperluan si penerima hibah untuk digunakan sebagai layaknya milik pribadi. Dalam KUH Perdata, sama sekali tidak mengakui hibah yang lain, kecuali hibah di antara orang-orang yang masih hidup. Hibah itu hanya mengenal benda-benda yang sudah ada, jika benda itu meliputi benda yang akan ada di kemudian hari, maka sekedar mengenai hal ini hibahnya adalah batal.

Setiap orang boleh memberi dan menerima sesuau sebagai hibah, kecuali oleh auran perundang-undangan dinyaakan idak cakap unuk iu. Agar orang-orang yang menerima hibah iu dapa menerima keunungan dari suau hibah, maka si penerima hibah itu harus ada pada saa pemberian hibah iu, dengan mengindahkan peraturan yang ercanum dalam Pasal 2 KUH Perdaa.

Suatu hibah tidak dapat ditarik kembali atau dipalsukan, kecuali dalam hal-hal sebagaimana termuat dalam Pasal 1688 KUH Perdata, yaiu: (1) karena tidak dipenuhi syarat-syarat dengan mana hibah lebih telah dilakukan; (2) jika si penerima hibah telah bersalah melakukan atau membantu melakukan kejahatan dengan maksud membunuh sipemberi hibah; (3) jika si penerima hibah menolak memberikan tunjangan nafkah kepada si pemberi hibah, padahal si pemberi hibah itu telah jatuh miskin.

Dalam hukum adat, yang dimaksud dengan hibah ialah harta kekayaan seseorang yang dibagi-bagikannya di antara anak-anaknya pada waktu ia masih hidup, penghibahan itu sering terjadi ketika anak-anak mulai berdiri sendiri atau ketiga anak mulai menikah dan membentuk keluarga sendiri. Penghibahan dilakukan ketika si pemberi hibah masih hidup dengan tujuan untuk menghindarkan percekcokan yang akan terjadi apabila ia telah meninggal dunia di antara anak-anaknya itu. Penghibahan itu terjadi kemungkinan juga sebagai akibat karena kekhawatiran si pemberi hibah ibu dari anak-anaknya itu adalah ibu sambung atau ibu tiri, atau juga karena di kalangan anak-anaknya itu terdapat anak angkat yang mungkin disangkal keanggotaannya sebagai ahli waris. Hibah adalah hukum adat juga sering terjadi karena maksud si pemberi hibah untuk menyimpang dari hukum waris yang berlaku di kalangan masyarakat yang erkenal Islaminya, hal ini biasanya berlaku pada masyarakat garis keibuan seperti di daerah Minangkabau.

Pasal 171 huruf g Kompilasi Hukum Islam (KHI), hibah adalah pemberian suatu benda secara sukarela dan anpa imbalan dari seseorang kepada orang lain yang masih hidup unuk dimiliki. Pengertian ini sama dengan definisi yang banyak disebut dalam kitap-kitap fikih radisional bahwa yang dimaksud dengan hibah adalah pemilikan sesuatu melalui akad tanpa menharapkan imbalan yang telah dikeahui dengan jelas ketika si pemberi hibah masih hidup. Dengan demikian dapat ditarik kesimpulan bahwa kerelaan dalam melakukan perbuaan hukum anpa ada paksaan dari pihak lain merupakan unsur yang harus ada dalam pelaksanaan hibah. Jadi asasnya adalah sukarela. 
Dalam praktik pelaksanaan penyelesaian sengketa hibah di Pengadilan Agama, sering ditemukan beberapa problem hukum yang memerlukan solusi untuk penyelesainnya, di antara hibah semua harta, ruju' dalam hibah, barang yang dihibahkan, hibah dan hubungannya dengan warisan dan orang yang menerima hibah (Manan, 2008: 131-133).

3. Wasiat

Dalam Kompilasi Hukum Islam disebutkan bahwa yang dimaksud dengan wasiat adalah pemberian suatu benda dari pewaris kepada orang lain atau lembaga yang akan berlaku setelah pewaris meninggal dunia (Pasal 171 huruf f). Ketentuan tentang wasiat terdapat dalam pasal 194209 yang mengatur secara keseluruhan prosedur tentang wasiat.

Wasiat tidak hanya dikenal dalam hukum Islam, tetapi dikenal juga dalam Hukum Perdata BW. Wasiat dalam hukum perdata dikenal dengan testamen yang terdapat dalam buku kedua bab ketiga belas. Dalam Pasal 875 BW dikemukakan bahwa surat wasiat (testamen) adalah suatu akta yang memuat pernyataan seseorang tentang apa yang dikehendakinya setelah ia meninggal dunia dan dapat dicabut kembali oleh orang yang menyatakan wasiat itu. Pernyataan kehendak yang merupakan amanat terakhir orang yang menyatakan wasiat itu dikemukakan secara lisan di hadapan notaris dan dua orang saksi.

Wasiat dalam hukum perdata harus dibuat dalam bentuk surat wasiat (testamen) dan pembuatan surat wasiat itu merupakan perbuatan hukum yang sangat pribadi. BW mengenal tiga macam bentuk surat wasiat itu yaitu 1. Wasiat olografis, yaitu surat wasiat tersebut harus diserahkan untuk disimpan pada seorang notaris dan penyerahan itu bisa dalam keadaan terbuka atau bisa juga dalam keadaan tertutup, 2. Wasiat umum, adalah surat wasiat yang dibuat oleh seorang notaris, dengan cara orang yang akan meninggalkan wasiat menghadap notaris serta menyatakan kehendaknya dan mohon kepada notaris agar dibuatkan akta notaris dengan dihadiri dua orang saksi, pembuat wasiat harus menyampaikan sendiri kehendaknya di hadapan saksi-saksi dan notaris mengerti juga bahasa pewaris tersebut, 3. Wasiat rahasia, adalah wasiat yang ditulis sendiri atau ditulis oleh orang lain yang digunakan untuk memenuhi kehendak terakhirnya. Surat wasiat model ini harus disegel, kemudian diserahkan kepada notaris dengan dihadiri empat orang saksi, penyegelan dilakukan di hadapan notaris. Sebaiknya pembuat wasiat harus membuat keterangan di hadapan notaris dan saksi-saksi bahwa yang termuat dalam segel itu adalah surat wasiatnya yang ia tulis sendiri atau yang ditulis orang lain dan ia menandatangani, kemudian notaris membuat keterangan yang isinya membenarkan keterangan tersebut (Manan, 2008: 150-151).

4. Kafalah

Kafalah secara bahasa artinya menggabungkan, jaminan, beban dan tanggungan. Sedangkan menurut istilah Kafalah merupakan jaminan yang diberikan oleh penanggung (kafil) kepada pihak ketiga untuk memenuhi kewajiban pihak kedua atau yang ditanggung (Antonio, 2009: 123). Dalam 
redaksi lain Kafalah berarti mengalihkan tanggung jawab seseorang yang dijamin dengan berpegang pada tanggung jawab orang lain sebagai penjamin.

Dari beberapa pengertian, dapat disimpulkan bahwa Kafalah adalah jaminan dari penjamin (pihak ketiga), baik berupa jaminan diri maupun harta kepada pihak kedua sehubungan dengan adanya hak dan kewajiban pihak kedua tersebut kepada pihak pertama. Konsep ini sedikit berbeda dengan konsep rahn yang juga bermakna barang jaminan, namun barang jaminan tersebut dari orang yang berhutang.

Di KUHPerdata pasal 1820 disebutkan bahwa penanggungan adalah suatu persetujuan dengan mana seorang pihak ketiga, guna kepentingan si berpiutang, mengikatkan diri untuk memenuhi perikatannya si berutang mana kala orang ini sendiiri tidak memenuhinya (Subekti, 1991: 14). Dalam Al-Qur'an ayat yang menjelaskan tentang jaminan adalah dalam Surat Yusuf ayat 72:

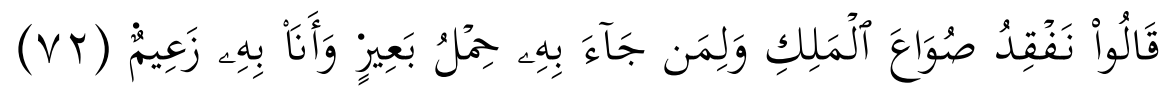

Artinya: "Penyeru-penyeru itu berkata: "Kami kehilangan piala Raja, dan siapa yang dapat mengembalikannya akan memperoleh bahan makanan (seberat) beban unta, dan aku menjamin terhadapnya".

Secara yuridis dalam Kitab Undang-Undang Hukum Perdata (KUHPerdata) terdapat istilah Borgtocht (penanggungan utang), Dalam pasal 1820 bab XVII bagian satu tentang sifat penangungan berbunyi: Penangungan adalah suatu persetujuan dengan mana seseorang pihak ketiga, untuk kepentingan orang yang berpiutang, mengikatkan diri untuk memenuhi perikatannya si berutang manakala orang tersebut sendiri tidak memenuhinya (Kitab Undang-Undang Hukum Perdata, 2004). Selain diatur dalam KUHPerdata, Borgtocht juga diatur dan dijelaskan dalam Kompilasi Hukum Ekonomi Syariah (KHES) dengan istilah Kafalah. Di dalam kedua bahan hukum tersebut mencakup semua hal-hal yang berkaitan dengan penanggungan atau penjaminan.

Dalam sistem hukum Indonesia berlaku pula Kitab Undang-Undang Hukum Perdata (KUHPerdata) yang merupakan peninggalan pemerintah Hindia-Belanda yang dahulu disebut "Buergerlijk Wetboek" (BW). Dalam praktiknya ketentuan KUHPerdata ini juga dipergunakan dalam berbagai transaksi syariah seperti dalam perbankan syariah di Indonesia. Penggunaan bahan hukum ini dapat dimaklumi karena pada masa-masa sebelumnya transaksi-transaksi perbankan dan keuangan lainnya menggunakan KUHPerdata sebagai rujukan di samping belum diterapkannya Kompilasi Hukum Ekonomi Syariah (KHES) dalam transaksi dimaksud.

Penanggungan utang dalam pandangan hukum Islam salah satunya ialah dengan Kafalah. Dengan menanggung utang seseorang yang disebut 
Kafil (penjamin) dan orang yang ditannggung utang tersebut yaiu makful 'anhu, sedangkan orang yang memberi utang disebut makful lahu. Adapun objek Kafalah itu sendiri salah satunya adalah uang, harta atau benda dan pekerjaan. Oleh karena itu, pada suatu masyarakat tertentu jika akan melakukan penanggungan kepada seseorang haruslah sesuai dengan ketentuan dan objeknya.

Mengenai penanggungan atau Kafalah di dalam Kompilasi Hukum Ekonomi Syariah (KHES) diatur dalam 26 pasal dan terdapat pada bab XII tentang Kafalah, yaitu mulai pasal 335 sampai pasal 361 (PPHIMM, n.d.). Sedangkan penanggungan atau Borgtocht di dalam Kitab Undang-Undang Hukum Perdata (KUHPerdata) terdapat dalam 30 pasal yaitu, pada bab XVII dimulai dari pasal 1820 sampai pasal 1850 (Kitab Undang-Undang Hukum Perdata, 2004). Akan tetapi sayangnya pada KUHPerdata disusun dalam tata bahasa Belanda yang disusun dalam bahasa Belanda yang diterjemahkan dalam bahasa Indonesia, jadi agak sedikit sulit dipahami oleh masyarakat Indonesia pada umumnya. Karena memang KUHPerdata tersebut merupakan hukum warisan Belanda.

Penanggungan dalam KUHPerdata lebih menekankan pada pembahasan penanggungan secara umum, artinya KUHPerdata ini merupakan peraturan atau Undang-Undang peninggalan Belanda dahulu, dan tidak memandang ras atau agama dalam pembahsannya. Seiring dengan perkembangan zaman, muncullah yang namanya Kompilasi Hukum Ekonomi Syariah atau yang dikenal isilah KHES. Di dalam KHES tersebut juga mengatur pasal-pasal mengenai penangungan. Penanggungan atau Kafalah di dalam KHES tersebut sudah mengalami perkembangan atau terdapat aturan-aturan tambahan yang belum terbahas didalam KUHPerdata.

Kompilasi Hukum Ekonomi Syariah (KHES) bukan termasuk Undang-Undang, akan tetapi merupakan sebuah hukum terapan materil yang dikeluarkan oleh Mahkamah Agung (MA). KUHPerdata dan Kompilasi Hukum Ekonomi S yariah secara undang-undang memang tidak setara, akan tetapi mempunyai kedudukan dan fungsi yang sama dihadapan hukum. Peraturan MA (PERMA) itu juga sudah dilegalkan oleh undangundang. Peraturan-peraturan penanggungan di dalam KUHPerdata dan KHES juga berbeda. Pengaplikasian penanggungan dalam keseharian dewasa ini lebih tertuju terhadap penanggungan dalam konsep perbankan syariah, yang berdasarkan dengan fatwa-fatwa dan merujuk kepada KHES. Sedangkan ketentuan yang ada dalam KUHPerdata khususnya dalam penanggungan jarang diaplikasikan didalam keseharian, karena sulitnya apabila terjadi wanprestasi di dalam penanggungan tersebut. Oleh karena itu masyarakat banyak menggunakan konsep penanggungan atau jaminan dalam perbankan.

\section{Upaya Positifisasi Hukum Ekonomi Syariah di Indonesia}


Peluang positifisasi (Azizy, 2002: 172-173) hukum Islam di Indonesia dijamin dalam pasal 2 Aturan Peralihan UUD 1945, pasal 29 ayat 2 UUD 1945, dan Dekrit Presiden 5 Juli 1959 yang masih mencantumkan Piagam Jakarta 22 Juni 1945. Sebelumnya, positifisasi hukum Islam dilakukan hanya sebatas hukum Islam sebagai salah satu sumber hukum nasional, yaitu dalam Undang-Undang Agraria tahun 1960, UU No. 1 Tahun 1974 Tentang Perkawinan, kemudian meningkat menjadi hukum Islam sebagai sumber hukum nasional dalam UU No. 7 Tahun 1989 Tentang Peradilan Agama, Inpres No. 1 Tahun 1991 Tentang Sosialisasi KHI, UU No. 41 Tahun 2004 Tentang Wakaf, UU Zakat, UU Haji dan UU No. 3 Tahun 2006 Tentang Perubahan atas UU No. 7 Tahun 1989 Tentang Peradilan Agama yang memberi perluasan kompetensi materiil bagi PA, termasuk dalam ekonomi syariah.

Belakangan, telah terjadi gejala baru dalam politik hukum nasional di mana hukum Islam semakin mendapatkan tempat yang sangat luas dalam sistem hukum dan perundang-undangan nasional. Kalau dibandingkan dengan tahun 1988-1990-an ketika KHI disusun, iklimnya sudah jauh berbeda. Saat itu banyak orang yang keberatan dan mengkritik secara pedas terhadap upaya perumusan KHI karena dibayang-bayangi dengan upaya pemberlakuan Syari'at Islam di Indonesia. Namun sekarang, kritik tersebut hampir tidak ada, padahal perluasan wewenang PA ke dalam Hukum Ekonomi Syari'ah (HES) termasuk lebih luas wilayahnya. Hal itu berbeda dengan hukum keluarga dalam Kompilasi Hukum Islam yang sudah menjadi kenyataan sosiologis dalam kehidupan umat Islam sejak lama karena dimensi 'ubudiyyah-nya yang lebih kuat. Salah satu faktornya gerakan Islamisasi ilmu pengetahuan dan praktek kehidupan umat Islam belakangan ini yang semakin massif. Disamping itu, banyaknya umat Islam yang peduli terhadap pemberlakuan hukum Islam di Indonesia di gelanggang politik dan lembaga-lembaga tinggi negara juga tidak dinafikan perannya.

Sebenarnya, praktek hukum keluarga (al-ahwal asy-syakhsiyyah) dengan hukum ekonomi syariah dalam kehidupan umat Islam itu ada perbedaan: hukum keluarga itu memang telah dipraktekkan oleh umat Islam sejak lama dengan kesadarannya, sehingga telah menjadi bagian dari adat- istiadat umat Islam. Dalam masyarakat adat dikenal banyak istilah, seperti orang Aceh mengatakan "hukom ngon Adat hantom cre lagee zat ngon sipheut" (hukum Islam dan hukum Adat tidak dapat diceraipisahkan karena erat sekali hubungannya, seperti hubungan zat dan sifat suatu barang atau benda), orang Minagkabau mengatakan "Adat dan Syara' sanda-menyanda, Syara' mengatao Adat memakai" (hubungan hukum Adat dengan hukum Islam erat sekali, saling topang-menopang, karena sesungguhnya yang dinamakan Adat yang benar-benar Adat adalah Syara' itu sendiri) (Ali, 1993: 201). 
Sedangkan hukum ekonomi syariah, secara umum belum dipraktekkan dan belum menjadi adat-istiadat dan sebuah kebiasaan umat Islam dalam kehidupan sehari-hari. Hukum ekonomi syariah secara kelembangaan hanya dipraktekkan lewat Lembaga Keuangan Syariah. Positifisasi ini berangkat dari gejala institusionalisasi hukum ekonomi syariah yang secara adat belum dipraktekkan oleh seluruh umat Islam. Kalau melihat langsung di lapangan, justru masih banyak sekali praktek ekonomi umat Islam yang semakin menyimpang dari hukum Islam dan semakin mengkristal menjadi semacam kebiasaan. Kalau dalam konteks Ushul Fiqh, disebut dengan 'urf fasid. Bahkan LKS-LKS yang menjadi barisan terdepan dalam penegakan hukum ekonomi syariah pun juga belum sepenuhnya menerapkannya, masih ada penyimpangan di sana sini.

Norma hukum Islam menghendaki pemberlakuan hukum oleh setiap pemeluknya (Anwar, 2002: 152). Dalam kajian hukum Barat terdapat teori ubi societas ibiius, dimana ada masyarakat maka di situ ada hukum. Menurut teori ini bahwa hukum itu tumbuh dan berkembang bersama masyarakatnya. Oleh karena itu dalam membuat hukum selalu mengakomodir kenyataan sosiologis masyarakatnya (Soekanto, 1980: 41). Dalam hukum Islam dikenal teori 'urf atau adat, sebagai salah satu metode istinbat hukum. Dalam teori ini hukum dirumuskan dengan mempertimbangkan adat istiadat masyarakat. Sehingga dalam kajian istinbat hukum Islam dikenal kaidah, "perubahan hukum itu (ditentukan) oleh perubahan waktu, tempat, dan adat-istiadat" (Rusli, 1999). Lebihlebih wilayah muamalat itu berkaitan dalam masyarakat secara langsung yang sarat dimensi sosiologisnya. Nabi sendiri telah memberikan isyarat sifat hukum muamalat yang dinamis dan terbuka dengan mengatakan, "kamu sekalian yang lebih mengetahui urusan dunianya." Kaitannya dengan fleksibelitas dalam hukum ekonomi syariah dikenal kaidah, "semua akad muamalat itu mutlak diperbolehkan sampai ada hukum yang melarangnya" (Ash-Shiddieqy, 1975: 417).

Oleh karena itu, akomodasi terhadap kenyataan sosiologis umat Islam yang berkaitan dengan praktek hukum ekonomi syariah diperlukan karena hal itu akan berdampak pada efektifitas dan respon di masyarakat serta prospek hukum ekonomi Islam itu sendiri. Di sinilah perlunya pendekatan sosiologis dalam legislasi hukum untuk masyarakat agar hukum-hukum yang dihasilkan berkaitan dengan Hukum Ekonomi Syariah bisa berjalan efektif dan tetap dalam koridor tatanan Syariat yaitu AlQur'an dan Hadist sebagai dasar landasan umat Islam dalam segala hal kehidupan. 


\section{Kesimpulan}

Hukum Ekonomi Syariah yang telah dipraktekkan dalam aktifitas di lembaga keuangan syariah, memerlukan wadah perundang-undangan agar memudahkan penerapannya dalam kegiatan usaha di lembaga-lembaga keuangan syariah tersebut. Dalam pengambilan keputusan di Pengadilan dalam bidang ekonomi syariah sangat dimungkinkan adanya perbedaan pendapat. Untuk menangkal itulah diperlukan adanya kepastian hukum sebagai dasar pengambilan keputusan di Pengadilan. Dengan demikian lahirnya Kodifikasi Hukum Ekonomi Syariah dalam sebuah Kitab-UndangUndang Hukum Perdata Islam menjadi sebuah keniscayaan.

Formulasi materi Kodifikasi Hukum Ekonomi Syariah tidak terdapat dalam Yurisprudensi di lembaga-lembaga peradilan di Indonesia. Meski demikian, yurisprudensi dalam kasus yang sama bisa dirujuk sepanjang tidak bertentangan dengan prinsip hukum ekonomi syariah. Artinya, keputusan hakim masa lampau itu difikihkan, karena dinilai sesuai dengan syariah. Yurisprudensi putusan ekonomi syariah, mungkin juga bisa dicari dari penerapan hukum adat di dalam putusan pengadilan yang ada di negara Indonesia yang sedikit banyak telah diinspirasikan oleh ketentuan hukum Islam. Yang paling bagus adalah merujuk Kitab UndangUndang Hukum Perdata Islam yang pernah dibuat di zaman Kekhalifahan Turki Usmani yang disebut Majalah Al-Ahkam Al-Adliyah KUHPerdata Islam ini dapat dikembangkan pembahasannya serta disesuaikan dengan perkembangan aktivitas perekonomian di zaman modern.

Hukum materil ekonomi syariah di Indonesia pada umumnya baru tersedia dalam bentuk fiqh para fuqaha' atau Fatwa Dewan Syariah Nasional Majelis Ulama Indonesia (DSN MUI) secara khusus, yang sebagiannya telah menjadi Peraturan Bank Indonesia melalui upaya positivisasi fatwa. Mengisi kekosongan perundang-undangan dalam bidang ini bagi kepentingan penyelesaian sengketa di pengadilan, maka Mahkamah Agung RI telah menerbitkan Peraturan Mahkamah Agung Nomor 02 Tahun 2008 tentang Kompilasi Hukum Ekonomi Syariah (KHES). KHES terdiri dari 4 Buku, masing-masing tentang Subyek Hukum dan Amwal, Akad, Zakat dan Hibah, dan Akuntansi Syariah. 


\section{Daftar Pustaka}

Ahmad, K. (1983). Studies in Islamic Economics. Leicester: The Islamic Foundation.

Ali, M. D. (1993). Hukum Islam, Pengantar Ilmu Hukum dan Tata Hukum di Indonesia (Cetakan ke). Jakarta: Raja Grafindo Rosada.

Antonio, M. S. (2009). Bank Syariah: Dari Teori ke Praktek (Cetakan ke). Jakarta: Gema Insani.

Anwar, S. (2002). Pengembangan Metode Penelitian Hukum Islam (Cetakn ke-). Yogyakarta: Penerbit ar-Ruzz Press.

ARFAH, A., OLILINGO, F. Z., SYAIFUDDIN, S., DAHLIAH, D., NURMIATI, N., \& PUTRA, A. H. P. K. (2020). Economics During Global Recession: Sharia-Economics as a Post COVID-19 Agenda. The Journal of Asian Finance, Economics and Business, 7(11), 1077-1085. https://doi.org/10.13106/jafeb.2020.vol7.no11.1077

Ash-Shiddieqy, H. (1975). Falsafah Hukum Islam. Jakarta: Bulan Bintang.

Azizy, A. Q. (2002). Eklektisisme Hukum Nasional, Kompetensi antara Hukum Islam dan Hukum Umum (Cetakan ke). Yogyakarta: Gama Media.

Fathonih, A., Anggadwita, G., \& Ibraimi, S. (2019). Sharia venture capital as financing alternative of Muslim entrepreneurs. Journal of Enterprising Communities: People and Places in the Global Economy, 13(3), 333-352. https://doi.org/10.1108/JEC-112018-0090

Hamid, M. A. (2007). Hukum Ekonomi Islam (Ekonomi Syariah) Di Indonesia Aplikasi dan Prospektifnya. Bogor: Ghalia Indonesia.

Kahf, M. (1987). Deskripsi Ekonomi Islam. ( diterjemahkan oleh R. Ka’bah, Ed.). Jakarta: Penerbit Minaret.

Kholid, M. (2018). PRINSIP-PRINSIP HUKUM EKONOMI SYARIAH DALAM UNDANG-UNDANG PERBANKAN SYARIAH. AsySyari'ah, 20(2), 145-162.

https://doi.org/10.15575/as.v20i2.3448

Kitab Undang-Undang Hukum Perdata. (2004) (Cetakan ke). Jakarta, Indonesia: Pradiya Paramita.

Manan, A. (2008). Aneka Masalah Hukum Perdata Islam Di Indonesia. Jakarta: Kencana Prenada Media Group.

Mingka, A. (n.d.). Urgensi Kodifikasi Hukum ekonomi Syari'ah.

PPHIMM. Kompilasi Hukum Ekonomi Syariah.

Rusli, N. (1999). Konsep Ijtihad asy-Syaukani, Relevansinya bagi 
Maulana Ira

Perubahan Hukum Islam di Indonesia. Ciputat: Logos Wacana Ilmu.

Sabirin, S. (2003). Perjuangan Keluar Dari Krisis. Yogyakarta: BPEF.

Soekanto, S. (1980). Pokok-Pokok Sosiologi Hukum (Cetakan ke). Jakarta: Rajawali.

Subekti, R. (1991). Hukum Perjanjian. Jakarta: Internusa. 